\title{
PENGARUH BI 7-DAY REPO RATE, CAR, BOPO, DAN DPK TERHADAP PROFITABILITAS BANK UMUM SYARIAH DI INDONESIA PERIODE 2015-2019
}

\author{
Ida Sholichatunnisa \\ Universitas Negeri Surabaya \\ Ida.17080694003@mhs.unesa.ac.id \\ Mariana \\ Universitas Negeri Surabaya \\ Mariana@unesa.ac.id
}

\begin{abstract}
This study aims to determine the effect of the BI 7-Day Repo Rate, Capital Adequacy Ratio (CAR), Operational Costs on Operating Income, Third Party Funds (TPF) on the profitability of Islamic Commercial Banks in Indonesia for the period 2015 to 2019. This study uses secondary data sources. obtained from the financial statements of each Islamic Commercial Bank that has been registered with the Financial Services Authority (OJK) from 2015 to 2019. The sample used in this study was 12 Islamic Commercial Banks using the purposive sampling method. The data analysis technique in this study uses multiple linear analysis techniques. The results of this test indicate that the BI 7-Day Repo Rate, $C A R$, and TPF partially have no effect on profitability, while OEOI has an effect on profitability. BI 7-Day Repo Rate, CAR, BOPO, and TPF simultaneously have an influence on the profitability of Islamic Commercial Banks.
\end{abstract}

Keywords: Influence of BI 7-Day Repo Rate, CAR, BOPO, and TPF

\begin{abstract}
ABSTRAK
Tujuan dari kajian ini ialah guna mengetahui pengaruh BI 7-Day Repo Rate, Capital Adequacy Ratio (CAR), Biaya Operasional Pendapatan Operasional (BOPO), serta Dana Pihak Ketiga (DPK) pada profitabilitas Bank Umum Syariah di Indonesia periode 2015 hingga 2019. Sumber data di kajian ini ialah data sekunder yang didapat melalui laporan keuangan masing-masing Bank Umum Syariah yang sudah terdaftarkan ke Otoritas Jasa Keuangan (OJK) dari tahun 2015 hingga 2019. Sampel pada kajian ini sejumlah 12 Bank Umum Syariah mempergunakan metode purposive sampling. Kajian ini mempergunakan teknik analisis linier berganda. Hasil pengujian pada kajian ini menunjukkan bahwa BI 7Day Repo Rate, CAR, dan DPK secara parsial tidak memengaruhi profitabilitas, sedangkan BOPO berpengaruh terhadap profitabilitas. Sedangkan BI 7-Day Repo Rate, CAR, BOPO, dan DPK secara simultan memengaruhi profitabilitas Bank Umum Syariah.

Kata kunci: Pengaruh BI 7-Day Repo Rate, CAR, BOPO, dan DPK.
\end{abstract}




\section{PENDAHULUAN}

Sesuai SK Menkeu RI No. 792/1990 lembaga keuangan ialah lembaga yang berkegiatan di sektor finansial, yaitu guna mengimpun pembiayaan, serta penyalurannya pada masyarakat guna mendanai pemodalan perusahaan. Lembaga finansial terklasifikasikan menjadi dua, terdiri atas perbankan dan bukan perbankan (Arthesa \& Handiman, 2006). Berdasar Perundang-Undangan Perbankan No. 10 Tahun 1998 bank terbagi menjadi tiga macam, yakni bank sentral, bank umum, serta BPR. Bank sentral ialah lembaga finansial negara yang bertanggung jawab mengelola serta melakukan pengawasan aktivitas lembaga finansial, maupun menjamin terciptanya tingkat ekonomi yang stabil pada kegiatan lembaga tersebut. Bank umum ialah bank yang berkegiatan usaha pemberian jasanya dilakukan secara konvensional atau berprinsip pada syariah Islam. Sedangkan untuk BPR yakni perbankan yang berkegiatan usaha dilaksanakan secara konvensional maupun syariah tetapi pada aktivitasnya tanpa memberi jasa. Islam memberikan panduan terhadap segala aspek kehidupan salah satunya pada sektor bisnis dan keuangan. Umat muslim memiliki keyakinan bahwa perbankan atau lembaga keuangan konvensional terdapat unsur riba yang telah dilarang oleh ajaran Islam. Perbankan syariah lahir guna menyanggupi keperluan umat Islam terkait produk yang berlandaskan asas syariah. Perbankan syariah menjauhi praktikpraktik yang telah dilarang oleh Allah dan Rasulnya seperti praktik riba (Firdaus, 2005). Berdasar data statistik bank syariah di Indonesia hingga 2019 ada 199 bank yang meliputi 14 Bank Umum Syariah, 20 Unit Usaha Syariah, serta 165 Bank Pembiayaan Rakyat Syariah (BPRS). Menurut (Ayyubi, Anggraeni, \& Mahiswari, 2017), apabila tingkat mediasi suatu perbankan dalam menghimpun dan menyalurkan dana semakin baik maka dapat dikatakan sektor ekonomi suatu negara mengalami perkembangan cukup pesat. Hal ini dikarenakan bidang finansial memiliki keterkaitan efisiensi pada perekonomian. Selaku badan yang memiliki peranan di sektor ekonomi, berarti dibutuhkan sebuah pemeliharaan dan kontrol kinerja yang baik. Pengestimasian kinerja pada perusahaan bisa dilaksanakan melalui beberapa indikator. Satu dari sekian banyak prosedur yang bisa dimanfaatkan guna mengestimasi taraf kesehatan suatu perusahaan oleh investor dan manajemen yaitu menggunakan rasio kesehatan laba atau dapat disebut rasio profitabilitas. Kapabilitas perusahaan selama mendapatkan keuntungan bisa dijadikan parameter daya kerja perusahaan itu. 
Apabila tingkat profitabilitasnya kian tinggi, berarti kinerja perusahaan tersebut semakin baik (Supriyadi \& Purnomo, 2019). Rasio yang dapat dimanfaatkan guna menentukan ukuran taraf daya laba perusahaan, yaitu ROA (Return on Asset). ROA, yaitu perbandingan pada keuntungan pascapajak terkait nominal keseluruhan aset. (Syah, 2018) memaparkan bila terdapat dua faktor penyebab profitabilitas perusahaan, meliputi eksternal dan internal. Faktor eksternal ialah faktor diluar kendali perusahaan seperti BI Rate. Sedangkan faktor internal ialah faktor yang bisa diatur pihak manajemen, seperti CAR (capital adequacy ratio), BOPO (biaya operasional pendapatan operasional), maupun Dana Pihak Ketiga (DPK). Apabila kian tingginya nilai CAR, berarti perusahaan dapat dikatakan mampu membiayai kegiatan operasional serta berkontribusi besar bagi profitabilitas perusahaan. Kajian milik (Mokoagow \& Fuady, 2015), menjelaskan jika nilai CAR semakin naik maka akan semakin naik pula nilai ROA. Tetapi, perihal ini tidaklah sama seperti data yang didapat peneliti dari data statistik perbankan syariah Indonesia. Nilai CAR tahun 2017 yang mengalami kenaikan tidak diimbangi dengan naiknya nilai ROA. Nilai ROA pada tahun 2017 sama seperti nilai ROA pada tahun sebelumnya. Semakin kecil nilai BOPO dapat diartikan kinerja manajemen perusahaan tersebut semakin baik karena dinilai mampu menggunakan sumber daya yang lebih efisien. Penelitian (Mokoagow \& Fuady, 2015), menjelaskan bahwa nilai BOPO yang kian kecil memperlihatkan kian efisien bank selama melakukan kegiatan usaha. Apabila penggunaan biaya operasional semakin efisien maka akan berpengaruh pada meningkatnya nilai profitabilitas. (Suryadi, Mayliza, \& Ritonga, 2020) memperjelas bila tingkat biaya operasional yang semakin tinggi dapat menurunkan profit dari Bank Umum Syariah tersebut. Berbanding terbalik dengan hasil penelitian sebelumnya, perbankan syariah Indonesia penunjukkan data pada 2017 biaya operasional terjadi penurunan sejak periode terdahulu, tetapi nilai ROA tidak mengalami kenaikan. Jumlah DPK yang semakin tinggi dapat menyebabkan peningkatan nilai profitabilitas. Penelitian (Hidayat \& Sunarsi, 2017), menjelaskan bila DPK memengaruhi bermakna pada ROA. Perihal tersebut berarti bila nilai DPK terjadi peningkatan, sehingga nilai ROA bakal meningkat. Namun data yang didapat dari Statistik Perbankan Syariah menunjukkan jumlah DPK tahun 2017 meningkat dari tahun sebelumnya tetapi hal tersebut tidak diimbangi dengan kenaikan nilai ROA. Perbedaan teori yang kuran sesuai pada data, serta perbedaan variabel serta periode yang dilakukan oleh penelitian sebelumyamaka peneliti menilai penting untuk melakukan penelitian yang 
kemudian membahas mengenai masalah tersebut berjudul "Pengaruh BI 7-Day Repo Rate, CAR, BOPO, dan DPK

\section{TELAAH LITERATUR}

\section{BI 7-Day Repo Rate}

Yaitu suku bunga kebijakan sesuai ketetapan Bank Indonesia, yang nantinya akan diumumkan kepublik. BI 7-Day Repo Rate adalah suku bunga rujukan terbaru hasil penetapan Bank Indonesia diberlakukan mulai 19 Agustus 2016 yang mengganti BI Rate. Sesuai BI, Instrumen BI 7-Day Repo Rate dipergunakan karena dinilai berpengaruh dan berhubungan secara cepat terhadap pasar uang, perbankan, pasar uang, dan sektor riil yang mendukung penekanan pasar keuangan terkhusus bagi pemakaian instrumen repo.

\section{Capital Adequacy Ratio (CAR)}

Dianggap sebagai rasio kecukupan yang dapat merepresentasikan kapabilitas perusahaan selama membiayai aktivitas operasionalnya serta mengantisipasi risiko dari aktivitas yang sedang dilakukan perusahaan tersebut (Mokoagow \& Fuady, 2015). Menurut ketetapan Bank Indonesia No. 10/15/PBI/2008, pendanaan minimal suatu perusahaan ialah $8 \%$. Perusahaan yang modalnya berkecukupan dapat dikatakan dalam profitabilitas yang tinggi, artinya apabila modal perusahaan kian tinggi, berarti kian sama tingi taraf daya laba perusahaan tersebut. terhadap Profitabilitas Bank Umum Syariah di Indonesia Periode 2015-2019”.

\section{Biaya Operasional Pendapatan Operasional (BOPO)}

Acap dikenal menjadi perbandingan efisiensi operasional. BOPO sering dimanfaatan guna menentukan ukuran tingkat kapabilitas manajemen perusahaan selama mengatur maupun mengelola dana operasional. Tingkat efisiensi perusahaan ketika beraktivitas operasionalnya memiliki pengaruh bagi tingkat penghasilan yang didapat oleh perusahaan. Apabila semakin efisien dalam penggunaan biaya operasional, berarti pendapatan yang didapat bakal mengalami peningkatan. Sebaliknya, jika biaya operasionalnya semakin besar maka akan berdampak pada penurunan pendapatan perusahaan (Mokoagow \& Fuady, 2015).

\section{Dana Pihak Ketiga (DPK)}

Yakni dana hasil himpunan masyarakat secara personal atau berbentuk badan usaha (Hidayat \& Sunarsi, 2017). Sesuai ketetapan BI No. 10/19/PBI/2008 Dana Pihak Ketiga merupakan kewajiban bank terhadap masyarakat berbentuk rupiah maupun valuta asing. Apabila terhimpunnya biaya pihak ketiga bernilai tinggi berarti tingkat profitabilitas bakal meningkat. 


\section{Return on Asset (ROA)}

Yaitu parameter guna menentukan rasio profitabilitas. Rasio ini merepresentasikan produktivias perusahaan ketika mengatur biaya dan menghasilkan laba bagi perusahaan X (Pramuka, 2010). Perhitungan ROA diperoleh melalui laba sebelum pajak, yang terbagi dengan jumlah

\section{METODOLOGI PENELITIAN}

\section{Jenis dan Sumber Data}

Kajian ini mempergunakan kuantitatif dan data sekunder. Pada kajian ini data sekunder didapat menggunakan prosedur pengamatan perbandingan keuangan perbankan yang terdaftarkan ke Otoritas Jasa Keuangan (OJK). Data pada kajian ini bersumber dari pelaporan keuangan tahunan tiap bank umum syariah media 2015 hingga 2019.

keseluruhan aktiva. Keuntungan sebelum pajak ialah keuntungan bersih melalui aktivitas perusahaan sebelum dikurangi pajak. Sedangkan jumlah keseluruhan aktiva yang dipergunakan dalam perhitungan ini ialah seluruh aktivita milik perusahaan (Suryadi, Mayliza, \& Ritonga, 2020).

\section{Populasi dan Sampel}

Populasi pada kajian ini, yaitu perbankan yang sudah terdaftarkan ke OJK dan menerbitkan pelaporan keuangan tahunan secara berkelanjutan mulai periode 2015 sampai 2019. Bank Umum Syariah yang terdaftarkan dalam OJK hingga akhir 2019 sejumlah 14 Bank. Namun dari 14 bank tersebut tidak semuanya memenuhi kriteria untuk dijadikan sampel. Dengan begitu, kajian ini mempergunakan sampel sejumlah 12 bank umum syariah, terdiri atas:

Tabel 1. Sampel Penelitian

\begin{tabular}{|c|c|}
\hline No. & Nama Bank \\
\hline 1 & PT Bank Muamalat Indonesia \\
\hline 2 & PT Bank Victoria Syariah \\
\hline 3 & PT Bank BRI Syariah \\
\hline 4 & PT Bank Jabar Banten Syariah \\
\hline 5 & PT Bank BNI Syariah \\
\hline 6 & PT Bank Syariah Mandiri \\
\hline 7 & PT Bank Mega Syariah \\
\hline 8 & PT Bank Panin Dubai Syariah \\
\hline 9 & PT Bank Syariah Bukopin \\
\hline 10 & PT Bank BCA Syariah \\
\hline 11 & PT Bank Tabungan Pensiunan Nasional Syariah \\
\hline 12 & PT Bank Net Indonesia Syariah \\
\hline
\end{tabular}

Sumber : Statistik Perbankan Syariah OJK 
Sampel pada kajian ini diambil berdasarkan prosedur purposive sampling berkriteria Bank Umum Syariah dan beroperasi di Indonesia sampai 2019.

Definisi Operasional dan Variabel Penelitian Variabel Independen

BI 7-Day Repo Rate

Yakni suku bunga kebijakan pengganti BI Rate melambangkan kewenangan moneter yang telah ditentukan Bank Indonesia. Instrumen BI 7-Day Repo
Rate digunakan karena dinilai bisa memberi pengaruh pasar uang secara cepat, perbankan serta sektor riil.

\section{Capital Adequacy Ratio (CAR)}

CAR merupakan parameter pembiayaan terkait kapabilitas perusahaan saat menutup risiko dari kegiatan yang sedang dilaksanakan, serta kapabilitas perusahaan selama membiayai aktivitas opersional. Nilai CAR didapatkan dengan menggunakan perhitungan berikut ini:

$$
\mathrm{CAR}=\frac{\text { modal sendiri }}{A T M R} 100 \%
$$

\begin{tabular}{llll} 
Biaya Operasional & \multicolumn{1}{c}{ Pendapatan } & operasional lainnya. Kian rendahnya nilai \\
Operasional (BOPO) & & & BOPO, berarti bank dianggap kian efektif \\
BOPO merupakan penggunaan saat & mempergunakan biaya. Berikut ini adalah \\
melakukan kegiatannya, meliputi biaya & perhitungan yang dapat digunakan untuk \\
bunga, tenaga kerja, pemasaran, serta & mengetahui nilai
\end{tabular}

$$
\mathrm{BOPO}=\frac{\text { biaya operasional }}{\text { penapatan operasional }} 100 \% 8
$$

\section{Dana Pihak Ketiga (DPK)}

DPK ialah biaya yang terkumpul dan didapat melalui masyarakat yang merepresentasikan tingkat kredibilitas bank di hadapan masyarakat. Kian bertambah jumlah DPK berarti tingkat kepercayaan bank pun kian meninggi. Nilai DPK didapatkan dengan menggunakan perhitungan dibawah ini :

$$
\text { Pertumbuhan DPK }=\frac{\text { DPKt-DPKt-1 }}{\text { DPKt-1 }} 100 \%
$$

\section{Variabel Dependen}

\section{Return on Asset (ROA).}

Variabel terikat pada kajian ini, yaitu ROA menjadi indikator guna menentukan rasio profitabilitas. Rasio ini merepresentasikan produktivias perusahaan selama mengatur pendanaan mereka dan menciptakan laba bagi perusahaan. Berikut ini adalah perhitungan yang dapat digunakan untuk mengetahui nilai ROA: 


$$
\mathrm{ROA}=\frac{\text { laba sebelum pajak }}{\text { total aset }} 100 \%
$$

\section{Teknik Pengumpulan Data}

Pengumpulan data pada kajian ini terlaksana atas penggunaan prosedur studi kepustakaan dan dokumenter laporan keuangan Bank Umum Syariah. Pelaporan keuangan ini didapat dari laman web tiap Bank Umum Syariah yang telah dipublikasi oleh OJK sejak periode 2015 hingga 2019.

\section{Teknik Analisis Data}

Pada kajian ini mempergunakan teknik analisis linier berganda sebagai metode linier regresi yang variabel terikatnya ialah fungsi linier melalui bermacam variabel independen. Model ini digunakan melihat keterkaitan pada variabel tergantung terhadap variabel bebas (Ghazali, 2011). Bentuk persamaannya, yaitu:

$$
\mathrm{Y}=\mathrm{a}+\mathrm{b}_{1} \mathrm{X}_{1}+\mathrm{b}_{2} \mathrm{X}_{2}+\mathrm{b}_{3} \mathrm{X}_{3}+\mathrm{b}_{4} \mathrm{X}_{4}+\mathrm{E}
$$

Penjelasan :

Y : ROA (variabel terikat)

a : Konstanta

$\mathrm{X}_{1} \quad$ : BI 7-Day Repo Rate

$\mathrm{X}_{2} \quad$ : CAR

$\mathrm{X}_{3}: \mathrm{BOPO}$

$\mathrm{X}_{4} \quad$ : DPK

$\mathrm{b}_{1} \quad$ : Koefisien variabel $\mathrm{X}_{1}$

$\mathrm{b}_{2} \quad$ : Koefisien variabel $\mathrm{X}_{2}$

$b_{3} \quad$ : Koefisien variabel $X_{3}$

$\mathrm{b}_{4} \quad$ : Koefisien variabel $\mathrm{X}_{4}$

E : Residual

\section{HASIL DAN PEMBAHASAN}

\section{Deskripsi Data}

Objek kajian ini, yakni Bank umum Syariah yang terdaftarkan ke OJK dan sudah mengeluarkan pelaporan keuangan tahunan secara berkelanjutan sejak periode penelitian yakni 2015 hingga 2019, maka terkumpul 12 Bank Umum Syariah. Dibawah ini adalah sebuah tabel yang disajikan dari hasil analisis deskriptif, yakni: 
Tabel 2. Uji Statistik Deskriptif

\begin{tabular}{|c|c|c|c|c|c|}
\hline Variabel & $\mathrm{N}$ & Min & Max & Mean & Std. Dev \\
\hline BI Rate & 34 & 4.25 & 7.50 & 5.6103 & 1.15173 \\
\hline CAR & 34 & 12.34 & 29.72 & 18.7715 & 4.60054 \\
\hline BOPO & 34 & 81.26 & 109.62 & 93.9438 & 5.63653 \\
\hline DPK & 34 & 1512.00 & 48687.00 & 17803.4706 & 15815.44140 \\
\hline ROA & 34 & -.08 & 1.97 & 0.7073 & 0.59238 \\
\hline
\end{tabular}

Sumber : Hasil Olah Data Sekunder

\section{Uji Asumsi Klasik}

\section{Uji Normalitas}

Bermaksud guna mengetahui model regresi dan residual yang terdistribusikan secara normal. Selain itu, pengujian normalitas juga berfungsi guna mengetahui sejauh mana data mendekati distribusi yang normal. Cara agar dapat melihat data bisa terbagikan secara nomal ataukah tidak adalah dengan Uji Kolmogorov Smirnov (Uji Parametrik). Pada kajian ini nilai Kolmogorov smirnov sejumlah 1,013 sedangkan nilai probabilitas Sig nya sejumlah 0,257 lebih besar ketimbang 0,05 berarti jika hasilnya memperlihatkan nilai probabilitasnya $>0,05$ bisa dianggap data terbagikan secara normal.

\section{Uji Multikolinieritas}

Mempunyai tujuan guna mencari tahu ada atau tidaknya keterkaitan antar-variabel independen. Jika terdapat korelasi artinya terdapat gejala multikolineritas, tetapi jika tidak ada tidak terdapat korelasi artinya tidak ada gejala multikolineritas. Cara untuk mengetahui ada gejala atau tidak ada gejala multikolineritas yaitu bila Nilai Tolerance lebih dari 0,100 , serta jika nilai VIF kurang dari 10,00 berarti bisa disebut tanpa ada gejala multikolineritas. Pada penelitian ini keempat variabel bebas memperlihatkan nilai tolerance lebih dari 0,100 dan nilai VIF kurang dari 10,00.

\section{Uji Heterokedastisitas}

Mempunyai tujuan guna mencari tahu model regresi ada atau tidaknya ketidaksesuaian variance dari residual tiap pengamatan. Metode guna mengetahui ada gejala atau tidak ada gelaja heterokedastitas bisa melalui mencermati tersebarnya titik-titik secara bergelombang, melebar atau menyempit serta persebaran titik di atas atau di bawah angka 0 di sumbu Y. Uji Heterokedastitas di lihat melalui gambar grafik Scatterplot, yaitu : 
Gambar 1. Uji Heterokedastisitas

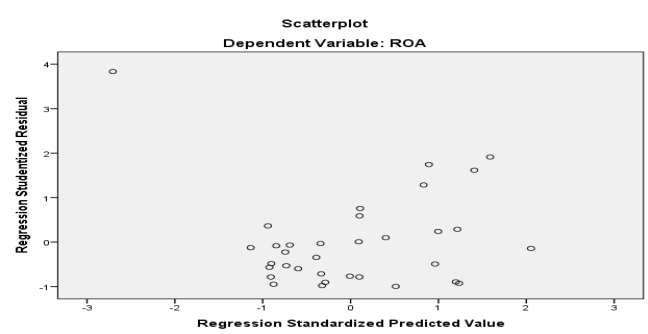

Sumber: Hasil olah data sekunder

Pada gambar grafik diatas menunjukkan pola titik tersebar secara melebar dan posisi titik-titik itu ada diantara, di atas, ataupun di bawah angka o sumbu $\mathrm{Y}$ artinya tanpa ada gejala heterokedastitas.

\section{Uji Autokorelasi}

Bermaksud mencari tahu model regresi linier apakah terdapat korelasi di periode t1 atau periode sebelumnya. Metode guna mencari tahu ada gejala atau tanpa adanya gejala autokorelasi mempergunakan cara melihat nilai pada Durbin Watson (d) dan juga di tabel Durbin Watson dengan signifikansi 0,05 . Penelitian ini menunjukkan nilai Durbin Watson sebesar 2,004. Dari banyak model kriteria untuk memustuskan kesimpulan pada uji autokorelasi penelitian ini menggunakan persamaan $d u<d<4-d u$ maka $1,7277<$ $2,004<2,2723$, menyimpulkan bila nilai Durbin Watson ada di $d u$ dan 4-du berdasar pada keputusan kriteria persamaan Durbin Watson bahwasannya persamaan tersebut menyatakan tidak adanya gejala autokorelasi.

\section{Uji Hipotesis}

\section{Uji Determinasi}

Uji Determinasi adalah proporsi yang menunjukkan berapa variasi variabel independent (X) seperti BI 7-Day Repo Rate, CAR, BOPO, dan DPK yang bisa mengungkapkan variabel dependent (Y) yaitu ROA. Nilai $R$ Square dianggap baik bila di atas $>0,05$, sebab nilai $\mathrm{R}$ Square berkisar dari 0-1. Terlampir penjelasan terkait hasil uji koefisien determinasi:

Tabel 3. Uji Determinasi

\begin{tabular}{|l|l|l|l|r|}
\hline $\begin{array}{l}\text { Mode } \\
1\end{array}$ & $\mathrm{R}$ & $\begin{array}{l}\mathrm{R} \\
\text { Square }\end{array}$ & $\begin{array}{l}\text { Adjusted R } \\
\text { Square }\end{array}$ & $\begin{array}{l}\text { Std. Error of } \\
\text { the Estimate }\end{array}$ \\
\hline 1 & $.937^{\mathrm{a}}$ & .879 & .862 & .22024 \\
\hline
\end{tabular}

Sumber : Hasil Olah Data Sekunder

Melalui hasil penjelasan tersebut nilai $\mathrm{R}$ Square sejumlah 0,879 atau setara dengan $87,9 \%$. Bisa menjelaskan bila nilai $\mathrm{R}$ Square nya baik karena diatas 0,05 dan dapat disimpulkan bawah variabel (X) seperti BI 7-Day Repo Rate, CAR, BOPO, dan DPK memiliki pengaruh pada variabel (Y) ROA sejumlah $87,9 \%$ lalu sisanya sejumlah $12,1 \%$ mempengaruhi variabel lain yang tanpa diamati di kajian ini. 


\section{Uji T}

Pengujian Signifikansi Individual (uji t) memiliki tujuan guna mencari tahu apakah tiap variabel independent atau bebas $(\mathrm{X})$ seperti BI 7-Day Repo Rate, CAR, BOPO, dan DPK memengaruhi secara signifikan terhadap varibel dependent atau terikat (Y) yaitu ROA. Dikatakan memiliki pengaruh bagi variabel $(Y)$ bila nilai Sig $<0,05$. Terlampir penjelasan terkait hasil pengujian

Tabel 4. Uji T

\begin{tabular}{|c|c|c|c|}
\hline \multicolumn{2}{|c|}{ Model } & $\mathrm{t}$ & \multirow{2}{*}{$\begin{array}{l}\text { Sig. } \\
.000\end{array}$} \\
\hline \multirow{5}{*}{1} & (Constant) & 11.934 & \\
\hline & BI RATE & .439 & .664 \\
\hline & CAR & -.376 & .710 \\
\hline & BOPO & -13.469 & .000 \\
\hline & DPK & -1.554 & .131 \\
\hline
\end{tabular}

Sumber : Hasil Olah Data Sekunder

Dari penjelasan tersebut akan dibahas satu persatu dari masing-masing varibel independent (X). Nilai proporsi untuk BI 7-Day Repo Rate sejumlah 0,664 > 0,05, berarti nilai itu lebih besar ketimbang 0,05 berarti BI 7-Day Repo Rate tanpa memengaruhi bermakna bagi varibel $(\mathrm{Y})$ ROA. Nilai proporsi CAR sebesar 0,710 > 0,05: nilai tersebut lebih besar ketimbang 0,05 berarti CAR pun tanpa memengaruhi bermakna bagi variabel (Y) ROA. Nilai proporsi BOPO sejumlah $0,000<0,05$ berarti nilai itu lebih kecil ketimbang 0,05 berarti bisa disebut BOPO memengaruhi secara bermakna bagi variabel (Y) ROA.
Sedangkan nilai proporsi DPK sejumlah $0,131>0,05$ berarti nilai itu lebih besar ketimbang pada nilai 0,05 maka pada DPK ini tanpa memengaruhi bermakna bagi variabel (Y) ROA.

\section{Uji F}

Uji signifikansi simultan mempunyai tujuan guna mencari tahu apakah sekelompok variabel bebas atau variabel $\mathrm{X}$ itu memengaruhi bermakna bagi variabel Y, dikatakan terdapat pengaruh secara simultan jika nilai probabilitas Sig nya < 0,05 . Terlampir penjelasan terkait hasil Uji Simultan (F) :

Tabel 5. Uji F

\begin{tabular}{|l|c|c|}
\hline \multicolumn{1}{|c|}{ Model } & F & Sig. \\
\hline Regression & 52.435 & $.000^{\mathrm{b}}$ \\
$\begin{array}{l}\text { Residual } \\
\text { Total }\end{array}$ & & \\
\hline
\end{tabular}

Sumber : Hasil Olah Data Sekunder 


\section{Pembahasan}

Pengaruh BI 7-Day Repo Rate terhadap ROA

Bank Syariah merupakan bank yang melakukan penghimpunan serta menyalurkan dana dengan imbalaan yang berdasar asas syariah. Bank Syariah tanpa mempergunakan sistem bunga selama menentukan imbal jasanya. Kesepakatan pembiayaan telah disetujui dan ditetapkan dalam syariah dan tidak boleh berubah mengikuti perubahan suku bunga acuan. Dengan demikian, naik maupun turunya suku bunga tidak bakal memengaruhi profitabilitas Bank Syariah. Pada kajian ini memperlihatkan hasil bila BI Rate sebagai tingkat suku bunga tanpa memengaruhi ROA. Hasil kajian ini memiliki persamaan dengan kajian milik (Fathoni, 2017), perihal ini dapat terjadi meskipun suku bunga mengalami kenaikan akan tetap menghasilkan spread margin sehingga tanpa memengaruhi profitabilitas Bank Syariah.

\section{Pengaruh CAR terhadap ROA}

Melalui hasil pengujian pada kajian ini, memperlihatkan hasil bila CAR tanpa memengaruhi bermakna bagi profitabilitas (ROA). Hasil kajian ini memperlihatkan bila keuntungan yang didapat oleh bank tidak dipengaruhi oleh tinggi rendahnya nilai kecukupan modal. Hal ini dapat dikarenakan meskipun suatu bank memiliki modal yang berkecukupan namun apabila tidak dapat menggunakannya secara efektif maka CAR tanpa memengaruhi bermakna bagi ROA. Hasil kajian ini sama seperti kajian milik (Wibowo \& Syaichu, 2013), memperlihatkan bila CAR tanpa memengaruhi bermakna bagi ROA.

\section{Pengaruh BOPO terhadap ROA}

Berdasar analisis data yang sudah diperoleh memperlihatkan bila BOPO memiliki pengaruh pada ROA. Perihal ini dapat disebabkan oleh tingkat efisiensi perbankan selama melaksanakan operasionalnya. Tingginya biaya operasional bakal memengaruhi penurunan profit yang akan diperoleh pihak perbankan syariah. Begitu juga sebaliknya jika biaya operasional yang dikeluarkan kian efisien berarti profit yang akan diterima oleh perbankan akan kian tinggi. Kajian ini memperlihatkan kesesuaian dengan kajian milik (Wibowo \& Syaichu, 2013), menjelaskan bila beban, serta biaya kredit yang kian tinggi dapat mengurangi permodalan dan keuntungan milik perbankan syariah.

\section{Pengaruh DPK terhadap ROA}

Pada penelitian ini memperlihatkan hasil bila DPK tanpa memengaruhi bermakna bagi ROA. Perihal ini dapat terjadi akibat meningkatnya jumlah DPK yang diterima oleh perbankan syariah tidak selamanya diimbangi dengan penyaluran dana dengan efektif. Bila DPK yang 
terkumpul seluruhnya disalurkan dalam suatu pembiayaan, maka akan menimbulkan risiko pembiayaan yang bermasalah. Risiko pembiayaan bermasalah yang tinggi bakal menjadikan profitabilitas bank syariah bakal menurun dan pihak perbankan akan mengalami kesulitan dalam mengembalikan dana masyarakat. Hasil kajian ini memiliki kesamaan dengan kajian milik (Fatimatuzzahro, 2017), memperlihatkan bila DPK tidak memengaruhi profitabilitas (ROA).

Pengaruh BI 7-Day Repo Rate, CAR, BOPO, dan DPK terhadap ROA

Berdasarkan analisa data yang telah

\section{SIMPULAN}

Berdasar hasil yang sudah dilaksanakan dengan proses mengumpulkan data, pengolahan data, serta analisis data terkait Pengaruh BI 7-Day Repo Rate, CAR, BOPO, dan DPK pada Profitabilitas Bank Umum Syariah di Indonesia 2015 hingg 2019, menyimpulkan, seperti:

1. BI 7-Day Repo Rate secara terpisah tanpa memengaruhi bermakna bagi profitabilitas (ROA). Perihal ini diakibatkan Bank Syariah tanpa mempergunakan sistem bunga dalam menentukan imbal dilakukan terdapat hasil yang menunjukan adanya pengaruh yang signifikan. Bisa menyimpulkan bila BI 7- Day Repo Rate, CAR, BOPO, dan DPK memengaruhi secara bersamaan pada profitabilitas Bank Umum Syariah.Hasil ini sama seperti tepri yang tersampaikan (Zulifiah \& Susilowibowo, 2014) yang menunjukkan bahwa BI Rate, CAR, dan BOPO memengaruhi secara simultan pada ROA. Perihal serupa pun terdapat di kajian milik (Setiawan \& Indriani, 2016), menunjukkan hasil bila variabel independen DPK, CAR, dan NPF memiliki pengaruh secara keseluruhan pada profitabilitas Bank Syariah.

$$
\begin{aligned}
& \text { jasanya. } \\
& \text { pembiayaan telah disetujui dan } \\
& \text { ditetapkan dalam syariah dan } \\
& \text { tidak boleh berubah mengikuti } \\
& \text { perubahan suku bunga acuan. } \\
& \text { Sehingga naik turunnya suku } \\
& \text { bunga tidak akan memengaruhi } \\
& \text { daya laba Bank. }
\end{aligned}
$$

2. CAR secara terpisah tanpa memengaruhi bermakna bagi ROA. Hal ini dapat terjadi karena meskipun perbankan memiliki modal yang berkecukupan namun apabila manajemen tidak mampu 
Jurnal Bina Akuntansi, Januari 2022, Vol.9, No.1, Hal. 22 - 36

menggunakan secara efektif

bermasalah yang

bisa

maka CAR tidak dapat

memengaruhi jumlah

memengaruhi nominal laba yang

didapat Bank Syariah.

3. BOPO secara terpisah bernilai yang memengaruhi profitabilitas.

Hal ini dapat terjadi karena apabila biaya operasional yang dikeluarkan oleh perbankan maka akan berdampak pada penurunan jumlah profit yang bakal didapatkan oleh Bank Syariah.

4. Dana Pihak Ketiga (DPK) tidak memengaruhi terpisah bagi profitabilitas. Perihal ini diakibatkan peningkatan jumlah DPK yang diterima oleh perbankan tidak seluruhnya diimbangi dengan penyaluran dana yang tepat dan efektif. Hal tersebut kedepannya akan menimbulkan risiko pembiayaan

\section{DAFTAR PUSTAKA}

Arthesa, A., \& Handiman, E. (2006). Bank dan Lembaga Keuangan Bukan Bank. Jakarta: PT. Indeks Kelompok Gramedia.

Ayyubi, S. E., Anggraeni, L., \& Mahiswari, A. D. (2017). Pengaruh Bank Syariah terhadap Pertumbuhan Ekonomi di Indonesia, "The Effect of Islamic Banking to Economic Growth in Indonesia". Jurnal Al-

Muzara'ah, Vol. 5, No. 2, 23376333.

Fathoni, A. B. (2017). Pengaruh Inflasi, Suku Bunga, dan BOPO terhadap ROA Perbankan. Surakarta: Universitas Muhammadiyah Surakarta.

Fatimatuzzahro. (2017). Pengaruh Dana Pihak Ketiga (DPK), Non Performing Financing (NPF), dan 
Penempatan Dana Pada Bank Indonesia Terhadap Prifitabilitas (studi empiris pada bank umum syariah tahun 2012-2015). Jurnal Ilmiah Riset Akuntansi, Vol. 6, No.2, 73-87.

Firdaus, M. (2005). Konsep dan Implementasi Bank Syariah. Jakarta: Renaisan.

Ghazali, I. (2011). Aplikasi Analisis Multivariate Dengan Program SPSS:. Semarang: Badan Penerbit: UNDIP.

Hidayat, A., \& Sunarsi, D. (2017). FaktorFaktor yang mempengaruhi dana pihak ketiga dan dampaknya terhadap profitabilitas (Survei pada BPR Syariah di Jawa Barat Tahun 2014-2017). Jurnal Proaksi , 1-12.

Mokoagow, S. W., \& Fuady, M. (2015). Faktor-Faktor yang Mempengaruhi Profitabilitas Bank Umum Syariah di Indonesia. EBBANK, Vol. 6, No. 1 , 33-62.

Pramuka, B. A. (2010). Faktor-Faktor yang Berpengaruh terhadap Tingkat Profitabilitas Bank Umum Syariah. . Jurnal Akuntansi, Manajemen Bisnis Dan Sektor Publik (JAMBSP) Vol. 7, No.1, 63-79.

Setiawan, U. N., \& Indriani, A. (2016). Pengaruh Dana Pihak Ketiga (DPK), Capital Adequacy Ratio (CAR), dan Non Performing Financing (NPF) terhadap Profitabilitas Bank Syariah dengan Pembiayaan sebagai Variabel Intervening. Diponegoro Journal of Management, Vol. 5, No. 4, 1-11. Supriyadi, D., \& Purnomo, B. S. (2019). Pengaruh Faktor Internal dan Eksternal Terhadap Profitabilitas Pada Bank Syariah di Indonesia. 7(1), Pengaruh Faktor Internal dan Eksternal Terhadap Profitabilitas Pada Bank Syariah di Indonesia. 7(1),. Jurnal Riset Akuntansi dan Keuangan, Vol. 7, No. 1, 55-66.

Suryadi, N., Mayliza, R., \& Ritonga, I. (2020). Pengaruh Inflasi, Biaya Operasional terhadap Pendapatan Operasional (BOPO), dan Pangsa Pasar terhadap Profitabilitas Bank Umum Syariah di Indpnesia Periode 2012-2018. Jurnal Tabarru' : Islamic Banking and Finance, 3(1), 1-10. Jurnal Tabarru': Islamic Banking and Finance, Vol. 3, No. (1) , 1-10.

Syah, T. A. (2018). Pengaruh Inflasi, BI Rate, NPF, dan BOPO Terhadap Profitabilitas Bank Umum Syariah di Indonesia. Journal el-Jizya, Vol. 6, No.1, 133-153.

Wibowo, E. S., \& Syaichu, M. (2013). Analisis Pengaruh Suku Bunga, Inflasi, CAR, BOPO, NPF terhadap Profitabilitas Bank Syariah. Diponegoro Journal of Management, 2(2), 1-10. Diponegoro Journal of 
Jurnal Bina Akuntansi, Januari 2022, Vol.9, No.1, Hal. 22 - 36

Management, Vol. 2, No. 2, 1-10.

Zulifiah, F., \& Susilowibowo, J. (2014).

Pengaruh Inflasi, BI Rate, Capital

Adequacy Ratio (CAR), Non

Performing Finance (NPF), Biaya

Operasional dan Pendapatan
Operasional (BOPO) terhadap Profitabilitas Bank Umum Syariah Periode 2008-2012. Jurnal Ilmu Manajemen, 2(3). Jurnal Ilmu Manajemen, Vol. 2, No. 3 , 759-770. 